\title{
Photoelectrochemical conversion using sprayed CdSe
}

\author{
J P MANGALHARA, R THANGARAJ and O P AGNIHOTRI \\ Department of Physics, Indian Institute of Technology, New Delhi 110016, India
}

\begin{abstract}
CdSe films on titanium have been prepared by spray pyrolysis and characterized by X-ray diffraction and X-ray photon spectroscopy. Photoelectrochemical solar cells with $4.84 \%$ conversion efficiency have been fabricated using these electrodes. Spectral response studies indicate absorption at sub-band gap energies. The band gap of $\mathrm{CdSe}$ as determined from photo-current studies was $1.66 \mathrm{eV}$. The flat band potential measured gives a value of $-1.54 \mathrm{~V}$ with reference to SCE for electrodes prepared using cadmium chloride and selenourea in the $1: 1$ ratio.
\end{abstract}

Keywords. CdSe thin films; spray pyrolysis; photoelectrochemical solar cell; sulphide polysulphide electrolyte.

\section{Introduction}

The photoelectrochemical cell furnishes an alternative to the commercially available photovoltaic cells for direct conversion of sunlight into electrical energy (Noufi and Tench 1980; Freese 1982). Polycrystalline liquid junction solar cells can give an energy conversion efficiency close to that of cells using single crystal electrodes at a very low cost (Reichman and Russak 1984).

Cadmium chalcogenides such as $\mathrm{CdSe}, \mathrm{CdTe}, \mathrm{CdS}$ etc are important materials used as photoanodes for photoelectrochemical solar cells. Cadmium selenide has shown great promise as a semiconductor material for photoelectrochemical conversion because of its near-ideal direct band gap $(1.7 \mathrm{eV})$. Several preparation techniques have been used to prepare polycrystalline thin films of CdSe for PEC applications, viz. elemental evaporation (Russak et al 1980), cold pressing (Makintosh et al 1983), painting from slurry (Xiao and Tien 1983), chemical solution growth (Rajeshwar et al 1981), spray pyrolysis (Chin-hsin et al 1981) etc.

Conversion efficiencies of $7 \cdot 2 \%$ and $14.2 \%$ for $n$-CdSe/sulphide-polysulphide and $n$-CdSe/ferro-ferricyanide systems respectively have been reported by Reichman and Russak (1984) using single crystal $n$-CdSe electrodes. In aqueous polysulphide electrolyte, power conversion efficiencies of $5.0 \%$ and $5.5 \%$ have been reported for CdSe thin films prepared by co-evaporation (Russak et al 1980) and chemical bath (Kainthla et al 1983). Chin-hsin et al (1981) reported a 5.5\% conversion efficiency for CdSe-sprayed films, photo-activated by illuminating the electrode in salt solution under short circuit condition.

Spray pyrolysis is a convenient and inexpensive method for preparing polycrystalline CdSe thin films. In the present paper our attempts in preparing CdSe films on titanium substrates by the spray method are reported.

\section{Experimental techniques}

The polycrystalline $\mathrm{CdSe}$ thin films were prepared by taking a $0.05 \mathrm{M}$ aqueous solution of selenourea $\left(\mathrm{NH}_{2} \mathrm{CSeNH}_{2}\right)$ and $0.05 \mathrm{M}$ aqueous solution of cadmium 
chloride $\left(\mathrm{CdCl}_{2}\right)$ as the starting solutions. To prepare films of $1 \mathrm{C} 1 \mathrm{~S}$ and $1 \mathrm{C} 2 \mathrm{~S}$ composition, the volume ratio of $1: 1$ and $1: 2$ of $\mathrm{CdCl}_{2}$ and $\mathrm{NH}_{2} \mathrm{CSe} \mathrm{NH}_{2}$ were taken. The solutions were mixed thoroughly and sprayed onto titanium substrates $1 \mathrm{~cm}$ $\times 2 \mathrm{~cm}$ ) heated at temperatures ranging from $200^{\circ} \mathrm{C}$ to $300^{\circ} \mathrm{C}$. The substrate temperature $220^{\circ} \mathrm{C}$ was found to be optimum for cell preparation. The titanium substrates were cleaned in a cold chromic-sulphuric acid mixture, etched in dilute HF and rinsed in de-ionized water. The substrates were kept on a hot plate which was heated using a resistive heater and a chromel-alumel thermocouple was used to monitor the substrate temperature. The spray rate was maintained at $5 \mathrm{ml} / \mathrm{min}$. The sprayer was rotated over the substrate during deposition to get a uniform film. The as-grown films were annealed in air at $450^{\circ} \mathrm{C}$ for 20 minutes. The electrodes were then etched in $20 \%$ chromic-sulphuric acid mixture and rinsed in deionized water and used as photoanodes. The electrolyte consisted of a solution of $2.5 \mathrm{M} \mathrm{Na}_{2} \mathrm{~S}, 1 \mathrm{MS}$ and $1 \mathrm{M}$ $\mathrm{KOH}$ in de-ionized water. A platinum foil worked as the counterelectrode.

A solar simulator (Kratos) was used as the light source for PEC studies. The I-V characteristics were studied using an I-V plotter (Anika). The spectral response was studied using narrow band interference filters. An X-ray generator (Philips PW 1729) with $\mathrm{CuK}_{\alpha}$ radiation was used for $\mathrm{X}$-ray diffraction studies.

\section{Results and discussion}

\subsection{X-ray diffraction and ESCA studies}

The X-ray diffraction patterns of $1 \mathrm{C} 1 \mathrm{~S}$ and $1 \mathrm{C} 2 \mathrm{~S}$ films on titanium are shown in figures 1 and 2 . The films were polycrystalline in nature and crystallinity improved after heat treatment. For $1 \mathrm{C} 1 \mathrm{~S}$ films (101) orientation and for $1 \mathrm{C} 2 \mathrm{~S}$ films (002) orientation were dominant.

Figures $3 a$ and $3 b$ show XPS studies of annealed 1C1S film. The scans were made in $\mathrm{Cd}-3 \mathrm{~d}$ region and $\mathrm{Se}-3 \mathrm{p}$ region. The position of $\mathrm{Cd}$ and Se peaks obtained from XPS results is given in table 1 and compared with results obtained by De Silva and Haneman (1980).

\subsection{I-V characteristics}

The as-grown films exhibited slight photovoltaic efficiency. Annealing the films in air followed by etching significantly improved the performance of the cells. Figures 4 and 5 show I-V characteristics of $1 \mathrm{C} 1 \mathrm{~S}$ and $1 \mathrm{C} 2 \mathrm{~S}$ photoanodes. The power conversion efficiency of $1 \mathrm{C} 1 \mathrm{~S}$ based cell was $4.84 \%$ and that for $1 \mathrm{C} 2 \mathrm{~S}$ was $1.96 \%$ under $70 \mathrm{mw} / \mathrm{cm}^{2}$ (AM 2) illumination. The low fill factor and short circuit current for $1 \mathrm{C} 2 \mathrm{~S}$ photo anodes can be attributed to the high series resistance owing to the high resistivity of these films. It has been shown that a high series resistance can reduce the shortcircuit current and the fill factor (Hovel 1975).

Chin-hsin et al (1981) reported enhancement in the efficiency of sprayed CdSebased cells by illuminating the photo-anode in salt solution under closed circuit condition. However, this treatment was not very successful for improving the performance of our cells. 


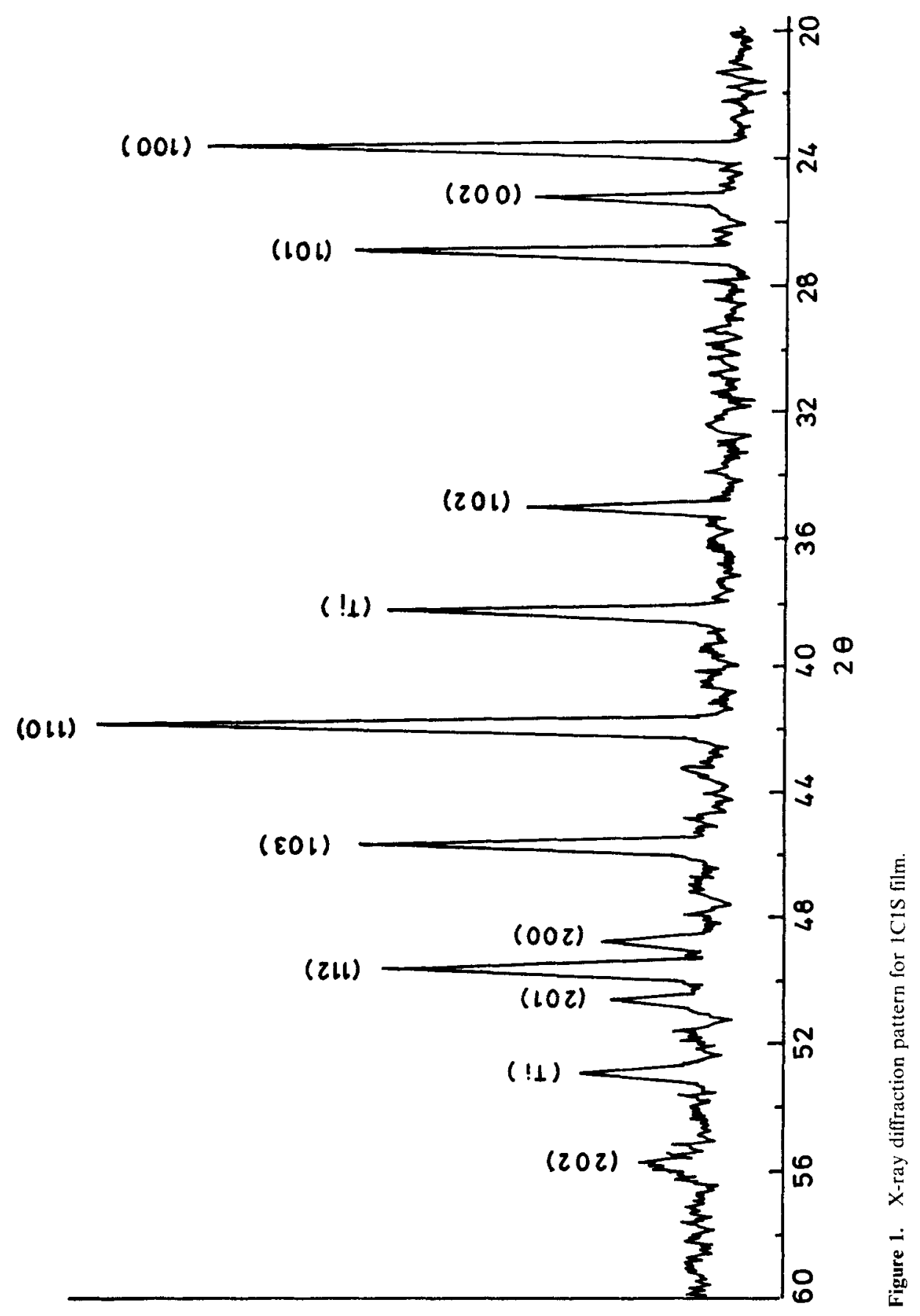




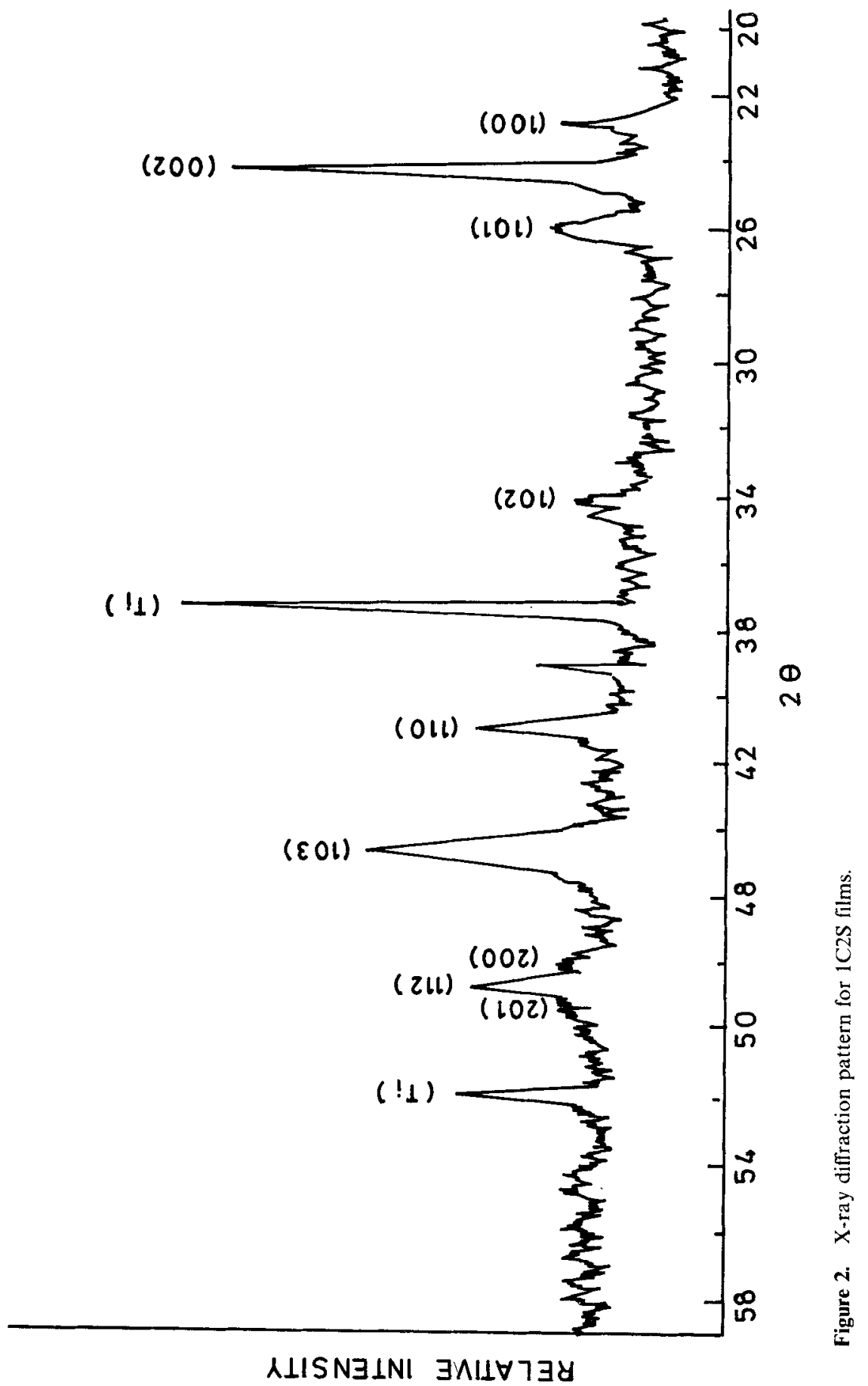




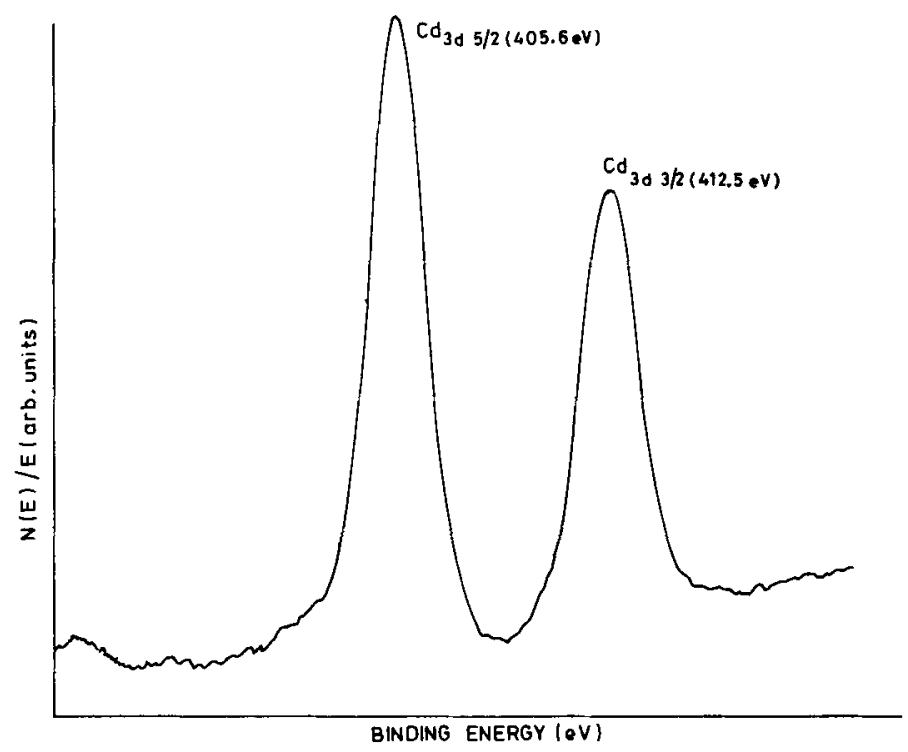

Figure 3a. ESCA pattern of IC $1 \mathrm{~S}$ film for $\mathrm{Cd}$

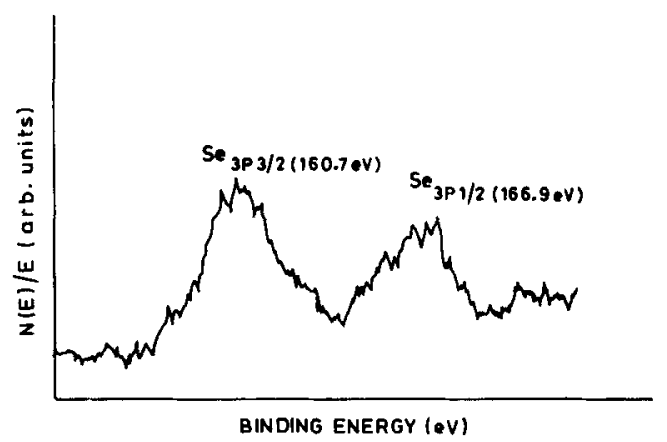

Figure 3b. ESCA pattern of $1 \mathrm{C} 1 \mathrm{~S}$ flim for Se.

Table 1. Electron binding energies (in eV).

\begin{tabular}{lcccc}
\hline & $\mathrm{Cd} 3 d_{3 / 2}$ & $\mathrm{Cd} 3 d_{5 / 2}$ & Se $3 p_{1 / 2}$ & Se $3 p_{3 / 2}$ \\
\hline $\begin{array}{l}\text { CdSe films electrodeposited } \\
\quad \text { (De Silva and Haneman 1980) }\end{array}$ & $411 \cdot 7$ & 405 & $166 \cdot 1$ & $160 \cdot 0$ \\
$\begin{array}{l}\text { Sprayed CdSe } \\
\text { (present studies) }\end{array}$ & 412 & 405.6 & 166.9 & $160 \cdot 7$ \\
\hline
\end{tabular}

\subsection{Spectral response measurements}

Figures 6 and 7 show the spectral response for $1 \mathrm{C} 1 \mathrm{~S}$ and $1 \mathrm{C} 2 \mathrm{~S}$ films. The spectral response of the two types of films was different. A high short circuit current was found for $1 \mathrm{C} 1 \mathrm{~S}$ films instead of $1 \mathrm{C} 2 \mathrm{~S}$ films. The spectral response in $1 \mathrm{C} 1 \mathrm{~S}$ films extends to longer wavelengths at sub-band gap energies. The band-tailing is due to 


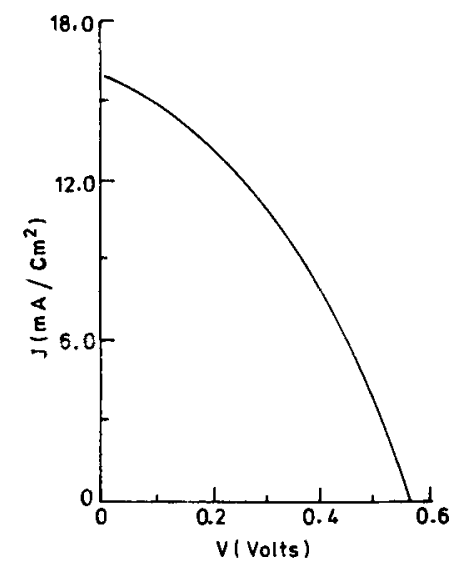

(4)

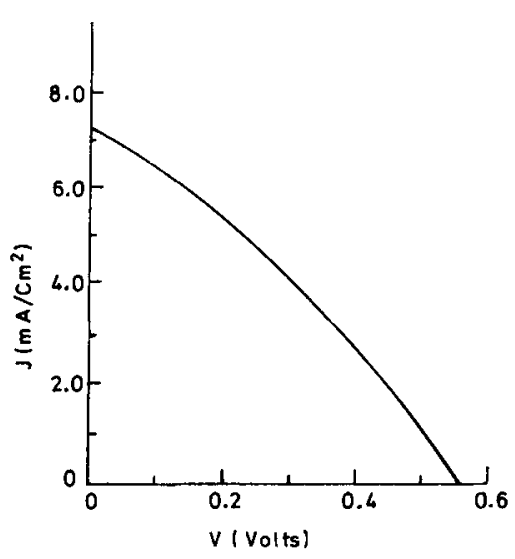

(5)

Figures 4 and 5. I-V characteristics for 4. $1 \mathrm{C} 1 \mathrm{~S}$ and 5. $1 \mathrm{C} 2 \mathrm{~S}$ electrodes.

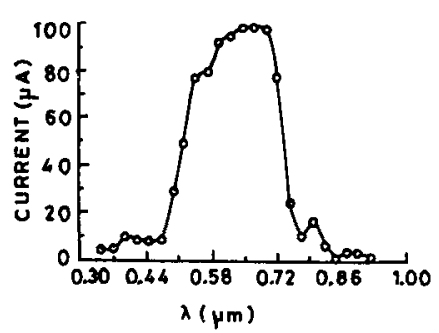

(6)

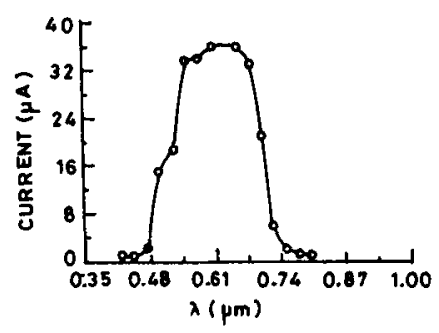

(7)

Figures 6 and 7. Spectral response for 6. 1C1S and 7. 1C2S electrodes.

absorption from grain boundaries, charge defects or impurities (Russak et al 1980). The peak at $0.79 \mu \mathrm{m}$ is perhaps due to defect absorption. At shorter wavelengths the current gain is less which is attributed to diffusion of the photogenerated majority carriers to the interface where recombination with photo-generated minority carriers takes place. The absorption due to the electrolyte starts at $0.5 \mu \mathrm{m}$.

\subsection{Determination of flat band potential}

The flat band potential $\left(V_{f b}\right)$ cannot be determined using Mott-Schottky plots as the direct contact between the titanium substrate and the electrolyte owing to the pin holes and cracks in the films, distort the expected straight line (Russak et al 1980). Net photo current, however, is not affected as the substrate is insensitive to illumination. The photocurrent is given by the relation (Butler 1977)

$$
J=e \Phi_{0}\left\{1-\frac{\exp \left(-W_{0}\left(V-V_{f b}\right)^{\frac{1}{2}}\right.}{1+L_{p} \alpha}\right\}
$$

where $e$ is the electronic charge, $\Phi_{0}$ the photon flux, $\alpha$ the absorption coefficient of the material, $L_{p}$ the minority carrier diffusion length, $\left(V-V_{f b}\right)$ the band bending and $W_{0}$ the depletion layer width. For $\alpha L_{p} \ll 1$, equation (1) can be written as: 


$$
V-V_{f b} \sim\left(J / \alpha W_{0} e \Phi_{0}\right)^{2}
$$

A plot of $J^{2}$ versus $V$ should be a straight line and the intercept of this line on the potential axis gives a flat band potential. Figures 8 and 9 show such plots for $1 \mathrm{C} 1 \mathrm{~S}$ and $1 \mathrm{C} 2 \mathrm{~S}$ electrodes in polysulphide electrolyte. The flat band potential with reference to SCE was $-1.54 \mathrm{~V}$ for $1 \mathrm{C} 1 \mathrm{~S}$ electrodes and $-1.55 \mathrm{~V}$ for $1 \mathrm{C} 2 \mathrm{~S}$ electrodes.

\subsection{Band gap determination}

For $\alpha L_{p} \ll 1$ and $W_{0}\left(V-V_{f b}\right)^{\frac{1}{2}} \ll 1$, we can expand equation (1) in the form:

$I \propto \alpha$.

Near the absorption edge $\alpha$ for a direct band gap material can be given as (Butler and Ginley 1980):

$$
\alpha=A\left\{\left(h v-E_{g}\right)^{\frac{1}{2}} / h v\right\} .
$$

A plot of $I^{2}$ vs $h v$ should be a straight line with an intercept on the energy axis giving the band gap $\left(E_{g}\right)$. Figure 10 shows such a plot for $1 \mathrm{C} 1 \mathrm{~S}$ photoanode in polysulphide electrolyte. The band gap thus determined is $1.66 \mathrm{eV}$ which is close to the reported value (Bube 1961).

\section{Conclusion}

CdSe thin films on titanium substrates were prepared by pyrolytic decomposition of suitable solutions for photoelectrochemical conversion application. The conversion

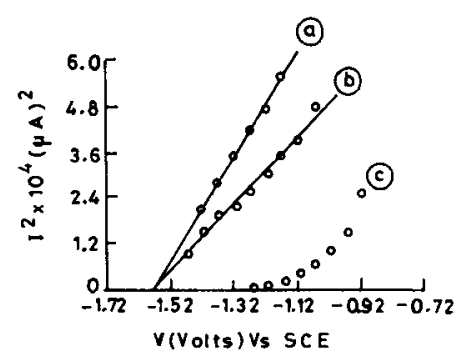

(8)

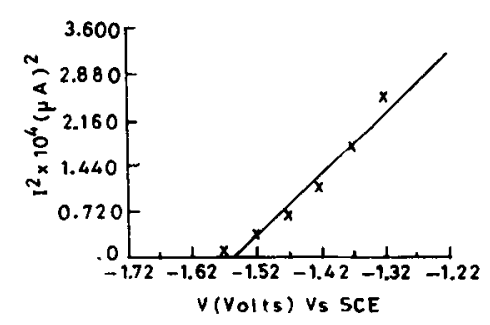

(9)

Figures 8 and 9. Flat band potential of 8. 1C1S electrode (a) $700 \mathrm{~nm}$, (b) $600 \mathrm{~nm}$ and (c) $525 \mathrm{~nm}$. 9. 1C2S electrode $(700 \mathrm{~nm})$.

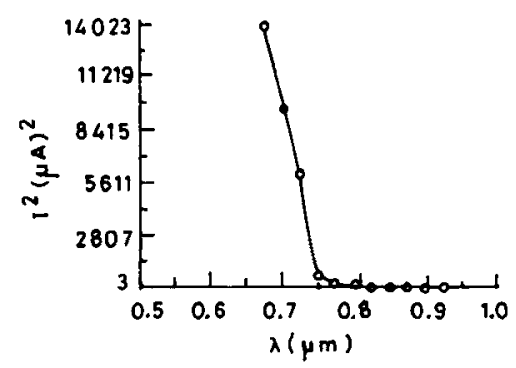

Figure 10. Band gap determination of $1 \mathrm{C} 1 \mathrm{~S}$ film. 
efficiency for $1 \mathrm{C} 1 \mathrm{~S}$ electrodes was $4.84 \%$ under $70 \mathrm{~mW} / \mathrm{cm}^{2}$ illumination. The flat band potential was found to be $-1.54 \mathrm{~V}$ with reference to SCE.

\section{Acknowledgements}

We are grateful to the Department of Non-Conventional Energy Sources, Ministry of Energy, Govt. of India and the Council of Scientific and Industrial Research, New Delhi for financial support.

\section{References}

Bube R H 1961 Photoconductivity in solids (New York: Wiley and Sons)

Butler M A 1977 J. Appl. Phys. 481914

Butler M A and Ginley D S 1980 J. Mater. Sci. 158

Chin-hsin, Liu J, Olsen J, Saunders D R and Wang J H 1981 J. Electrochem. Soc. 1281224

De Silva K T L and Haneman D 1980 J. Electrochem. Soc. 1271554

Freese K W 1982 J. Appl. Phys. Lett. 40275

Hovel H J 1975 Semiconductors and semi-metals Vol. 11, Solar cells, (New York: Academic Press)

Kainthla R C, Mc Cann J F and Haneman D 1983 Solar Energy Mater. 7491

Makintosh A, Wessel S, Guibaly F E and Colbow K 1983 Solar Energy Mater. 969

Noufi R and Tench D 1980 J. Electrochem. Soc. 127188

Rajeshwar K, Thompson L, Singh P, Kainthla R C and Chopra K L 1981 J. Electrochem. Soc. 1281743

Reichman J and Russak M A 1984 J. Electrochem. Soc. 131796

Russak M A, Reichman J, Witzke H, Deb S K and Chen S N 1980 J. Electrochem. Soc. 127275

Xiao X and Tien H T 1983 J. Electrochem. Soc. 13855 